TECHNICAL NOTES AN D MANUALS

Assessing The Impact Of Fiscal Shocks On Output In MENAP Countries

Prepared by Martin Cerisola, Chadi Abdallah, Victor Davies, and Mark Fischer Middle East and Central Asia Department

I NT ER NA T IO NA L O NOTARY FUN D 
TECHNICAL NOTES AND MANUALS

\section{Assessing The Impact Of Fiscal Shocks On Output In MENAP Countries}

Prepared by

Martin Cerisola, Chadi Abdallah, Victor Davies, and Mark Fischer

Middle East and Central Asia Department

I NTER N A T I O NAL MONETARY FUND 
INTERNATIONAL MONETARY FUND

Middle East and Central Asia Department

\section{Assessing The Impact Of Fiscal Shocks On Output In MENAP Countries}

Martin Cerisola, Chadi Abdallah, Victor Davies, and Mark Fischer.

January 2015

DISCLAIMER: This Technical Guidance Note should not be reported as representing the views of the IMF. The views expressed in this Note are those of the authors and do not necessarily represent those of the IMF or IMF policy.

\begin{tabular}{|l|l|}
\hline JEL Classification Numbers: & E62; H30; H50 \\
\hline Keywords: & Fiscal policy, fiscal multipliers \\
\hline Author's E-Mail Address: & $\begin{array}{l}\text { MCerisola@imf.org; CAbdallah@imf.org; VDavies@imf.org; } \\
\text { MFischer@imf.org }\end{array}$ \\
\hline
\end{tabular}




\section{TECHNICAL NOTES AND MANUALS}

\section{Assessing The Impact Of Fiscal Shocks On Output In MENAP Countries}

\section{Executive Summary}

This note is a reference guide to the econometric work on fiscal multipliers for MENAP countries ${ }^{1}$. Spending and tax multipliers are estimated from conventional VAR models and identified using a sign-restrictions approach. A MENAP fiscal multiplier template is also developed linking explicitly the fiscal to the real sector. The template-which builds on the FAD fiscal multiplier template-effectively allows desks to incorporate MENAP-specific fiscal multiplier estimates in their fiscal analysis and macroeconomic projections. Section I explains the motivation for estimating spending and tax revenue multipliers for MENAP countries. Section II details the econometric approach used in estimation. Section III presents and discusses the findings on fiscal multipliers in MENAP countries. Section IV presents a brief discussion of a back-of-theenvelope approach that allows MENAP desks with limited country data to derive values for fiscal multipliers based on country-specific characteristics. Section V explains the most salient features of the MENAP template, and demonstrates how to use the fiscal multiplier estimates and country data as inputs to project the impact of fiscal shocks on output.

Prepared by: Martin Cerisola, Chadi Abdallah, Victor Davies, and Mark Fischer.

Approved by: Daniela Gressani

This note has benefited from comments provided by MENAP desks, including Kadima Kalonji, as well as staff from the Fiscal Affairs Department, most notably Martine Guerguil and Abdel Senhadji.

1 The analysis in this note covers 19 countries in the Middle East, North Africa, Afghanistan, and Pakistan (MENAP) region. 


\section{TABLE OF CONTENTS}

INTRODUCTION

THE ECONOMIC APPROACH

Empirical Model and Identification $\underline{5}$

Data and Estimation $\underline{6}$

EMPIRICAL FINDINGS

"BACK OF THE ENVELOPE" APPROACH 11

THE MENAP FISCAL MULTIPLIER TEMPLATE

Main Features of the Multiplier Template 12

$\begin{array}{ll}\text { Using Fiscal Multiplier to forecast Real Output } & 13\end{array}$

An Illustration: Comparing the effects of Two Adjustment Scenarios 13

References $\underline{26}$

Appendices

1. Data Definitions and Sources

2. The Identification Procedure Using Sign-Restrictions 16

3. Fiscal Multipliers Estimates and Confidence Intervals

4. A Step-by-Step User Guide for the MENAP Fiscal Multiplier $\underline{22}$ 


\section{INTRODUCTION}

The relationship between fiscal policy and the real economy has generated renewed interest among policymakers since the onset of the Great Recession of 2008-09. This owes much to the critical role of fiscal policy in stimulating growth during that episode, as well as to the emerging challenges associated with fiscal adjustment for macroeconomic stability and growth in advanced economies. For many MENAP countries, the impact of the Great Recession has been compounded, in some cases, by the aftermath of the Arab Spring, which has resulted in large fiscal deficits and high public debt. This poses significant risks to stability, employment creation, and sustainable growth. In many of these countries, substantial and prolonged fiscal consolidation will be necessary to maintain fiscal sustainability and rebuild buffers. This seems particularly important in an environment that is characterized by high unemployment and weak growth prospects, against a backdrop of high global and regional uncertainties.

The need for fiscal consolidation and for preserving inclusive growth underscores the importance of better understanding the relationship between government spending and taxes, and economic growth ${ }^{2}$. The use of fiscal multipliers may help improve the understanding of fiscal measures on growth and increase the accuracy of growth forecasts, thus helping to better balance macroeconomic stability and growth. However, since fiscal multipliers bring into play the relatively short-term impact of fiscal shocks on output, other factors need to be incorporated when setting fiscal policies that aim at achieving fiscal sustainability in the long-term.

There is limited consensus in the literature on both the estimation method and the size of fiscal multipliers. Evidence suggests that they tend to vary over time and across countries. They can also depend on the state of the business cycle, the economic fundamentals, and the type of fiscal instrument used, among other factors. The empirical evidence is extensive for advanced economies but less so for MENAP countries ${ }^{3}$. Estimates for advanced economies suggest that key determinants for the size of fiscal multipliers include the state of the business cycle, ${ }^{4}$ "leakages" through imports, the marginal propensity to consume, the prevalence of Ricardian Equivalence, and exchange rate flexibility. More recently, Christiano et al., (2010) argue that government spending multipliers tend to be higher under a binding zero lower bound on interest rates. Blanchard and Leigh (2013) suggests that fiscal multipliers may have actually been higher than previously estimated, particularly since the onset of the global financial crisis in advanced economies with binding zero-bound constraints on interest rates.

Although MENAP countries have not faced a zero lower bound on interest rates, they exhibit other important characteristics which may imply larger fiscal multipliers. First, households tend to face binding liquidity constraints and have limited access to financial markets,

2 See Kochhar et al., Guidance Note on Jobs and Growth Issues in Surveillance and Program Work; IMF Policy Paper, September 2013. 3 Espinoza and Senhadji (2011) present important empirical evidence on fiscal multipliers for the GCC.

4 Baum, Poplawski-Ribeiro, and Weber (2012) show that the position in the business cycle affects the impact of fiscal policy on output.

Technical Notes and Manuals 15/01 | 2015

CInternational Monetary Fund. Not for Redistribution 
which may imply that consumption depends more on current income, and that investment depends more on current rather than future profits (Eggertsson and Krugman 2012). Second, MENAP countries frequently exhibit sizable economic slack, as reflected in negative output gaps and high levels of unemployment. Both of these characteristics suggest that any crowding out of private sector activities due to government spending could be potentially limited, thus implying higher fiscal multipliers (Blanchard and Leigh 2013).

This note relies on and extends the Guidance Note prepared by the Fiscal Affairs Department (FAD) on fiscal multipliers. ${ }^{5}$ It aims at increasing the number of Fund member countries-in particular those of the MENAP region-with estimated fiscal multipliers. To do so, the note presents estimates of fiscal multipliers for tax revenues and for different categories of spending, using annual data for 19 MENAP countries over 1990-2008 (see, Abdallah, Cerisola, Davies, and Fischer, forthcoming 2015) ${ }^{6}$. We pool the data across countries, rather than provide estimates on a country-by-country basis, dividing the sample into country groups. ${ }^{7}$ The first grouping is done according to the regional and economic classification, as presented in MENAP's Regional Economic Outlook (REO): MENAP, GCC, MENAP Oil Importers, MENAP Oil Exporters, and Arab Countries in Transition (ACTs). In the second grouping, countries are classified based on their economic fundamentals, relative to other countries in the MENAP sample: trade openness, income level, and exchange rate flexibility. We focus on three measures of spending: current expenditures, government consumption (excluding subsidies and transfers), and government investment expenditures. Data definitions and country groups are detailed in Appendix 1.

Estimates show that fiscal multipliers among the countries in the sample tend to be small, except for those multipliers associated with government investment spending, which generally exceed unity. For the average MENAP country, fiscal multipliers for current spending, government consumption and government investment spending are 0.5, 0.8, and 1.1, respectively. The tax revenues multiplier is estimated at around -0.4 . We also find significant variation in the size of these multipliers across the different MENAP regions. We show that such variation is explained by differences in economic fundamentals, including openness to trade, the level of income, and the flexibility of the exchange rate. Our estimates are generally consistent with theoretical priors, and are in line with the evidence from the literature for other economies and categories of spending and taxes.

5 Guidance Note on Fiscal Multipliers, prepared by Luc Eyraud, Lorenzo Forni, and Anke Weber (all FAD), and Nicoletta Batini (EUR). 6 The group of countries that is covered in this analysis, and for which sufficient data are available, comprises the following 19 countries: Algeria, Bahrain, Djibouti, Egypt, Iran, Jordan, Kuwait, Lebanon, Libya, Oman, Morocco, Pakistan, Qatar, Saudi Arabia, Sudan, Syria, Tunisia, the United Arab Emirates, and Yemen.

7 Estimating country-specific fiscal multipliers is not feasible as it requires long time series data that- to the best of our knowledge - are not available for most countries in the sample. 


\section{THE ECONOMIC APPROACH}

\section{Empirical Model and Identification}

A fiscal multiplier is defined as the ratio of a change in real output to an exogenous discretionary change in real government spending or real net tax revenues. Since fiscal multipliers may differ across forecast horizons, we focus on a common measure of the fiscal multiplier, the peak or maximum multiplier over the first four years after the fiscal shock, defined as: ${ }^{8}$

$$
F M=\frac{\max _{\mathrm{T}}\left(\mathrm{y}_{\mathrm{t}+\mathrm{T}}\right)}{\mathrm{f} / \mathrm{y}}
$$

Where $\mathrm{y}_{\mathrm{t}}$ denotes the dynamic response of real output in period $\mathrm{t}$ to a shock in the fiscal variable, and $\mathrm{f} / \mathrm{y}$ is the average share of the fiscal variable in output over the sample period. Thus, the fiscal multiplier measures the effect of a $\$ 1$ change in spending or a $\$ 1$ change in tax revenue on the level of output. Our aim is to estimate $y_{t}$ To this end, we estimate the following Panel Vector Autoregression (PVAR) model:

$$
\mathrm{Y}_{n, t}=\sum_{-\mathrm{k}=1}^{\mathrm{K}} B_{\mathrm{k}} \mathrm{Y}_{\mathrm{n}, \mathrm{t}-\mathrm{k}}+\varepsilon_{n, t}
$$

Where $Y_{n, t}$ is a vector of macroeconomic variables for a given year $t$ and country $n$. The matrix of reduced form coefficients $B_{\mathrm{k}}$ consists of the own-effects and cross-effects of the kth lag of the variables on their current observations. $\sum$ is the covariance matrix of the residuals $\varepsilon_{t}$. The system in equation ( 1 ) is the reduced form from a structural VAR model. Our interest lies not in the reduced form shocks, but in identifying how the variables in $Y_{n, t}$ respond to the structural shocks. We can identify these shocks (and the response of the variables to them) by imposing identifying restrictions on the reduced form system above. The structural counterpart to equation (1), in moving average form, is:

$$
\mathrm{Y}_{n, t}=(I-B L)^{-1} D u_{n, t}
$$

Where the matrix $D$ is diagonal so that the vector of structural errors $u$ consists of orthogonal white noise shocks, and their covariance matrix is normalized to be the identity matrix. Once we identify $D$ from the above mapping, we obtain the dynamic responses of interest. Indeed, we need not fully identify $D$ because we care only about three shocks: a government spending shock, a tax revenue shock, and a business cycle shock. We identify these shocks using the robust sign-restrictions approach proposed originally in Faust (1998), Uhlig (2005), and Mountford and Uhlig (2009), and generalized by Rubio-Ramirez, Waggoner and Zha (2010). In particular, we identify a government spending shock as one that causes government spending to rise. A tax revenue shock is identified by a positive response of tax revenues. The fiscal shocks are assumed to be mutually uncorrelated and orthogonal to a business cycle shock, which is identified as one that causes real output, real tax revenues and real private consumption to move in the same direction over a selected horizon. The sign restric-

8 Most studies assume that the effect of discretionary fiscal policy is temporary (see, FAD guidance note on Fiscal multipliers). On average, the maximum impact in our models occurs after around three years, which is generally consistent with findings of other studies

Technical Notes and Manuals 15/01 | 2015 
tions are imposed for up to two years after the shock. This identification scheme essentially implies that we can separate, for example, an increase in tax revenues due to a business cycle expansion from an increase in tax revenues caused by a change in tax policy. In addition, requiring business cycle shocks to be causally prior to fiscal shocks, essentially means that output movements are mostly explained by business cycle shocks, while the remaining effects are seen as estimates of the impact of fiscal policy. This identification procedure is agnostic in the sense that it only imposes a limited number of restrictions on the sign of the impulse responses of the fiscal variables, leaving the output response unrestricted. ${ }^{9}$

The sign-restrictions approach has many advantages over alternative identification schemes, especially in the case of countries where only annual data are available, such as MENAP countries. Other approaches for identifications in the context of VARs, such as the Cholesky approach, impose zero restrictions on the contemporaneous impact matrix which may be hard to justify on theoretical grounds. The widely used approach of Blanchard and Perotti (2002) is very useful, but relies on the existence of reliable (non-interpolated) quarterly data over a sufficiently long period of time, and is not compelling (and should not be used) at the annual frequency (see, Blanchard and Perotti 2002). ${ }^{10}$

\section{Data and Estimation}

In our baseline model, we include four variables in $\mathrm{Y}_{n, t}:$ real government spending (e.g., current spending, government consumption, or government investment spending), real GDP, real private consumption, and real net tax revenues. ${ }^{11}$ We transform variables into natural logs before estimation. The optimal lag $k$ used was set equal to 2 , as indicated by conventional lag specification tests. We use Bayesian methods to estimate the posterior density of the parameters of interest in equation (1), conditional on observing annual data over 1990-2008 for the 19 MENAP countries for which sufficient data were available. ${ }^{12}$ We choose to pool the data across countries rather than provide estimates on a country-by-country basis due to data limitations. With the exception of handful of countries, the sample size for a typical country is equal to 20 observations. As mentioned earlier, we divide the sample into a number of country-observation groupings and estimate and compare the fiscal multipliers across categories.

We estimate the posterior density using the sign-restrictions approach, noting that $B$ and $\sum$ are directly identified from estimation of the parameters in equation (1). We assume a Gauss-

\footnotetext{
9 The sign-restrictions approach has been widely used in identifying a wide range of economic shocks, including fiscal policy shocks (Mountford and Uhlig 2009), monetary policy shocks (Uhlig 2005) and housing market shocks (Abdallah and Lastrapes 2013).

10 The estimation of fiscal multipliers using annual data presents a shortcoming because it may fail to fully capture the dynamic effects of fiscal variables on GDP if such interactions occur within a year. Nevertheless, using annual data somehow addresses the critique that fiscal shocks identified within structural VARs using monthly or quarterly data suffer from an "expectation" problem because shocks tend to be predicted when using high frequency data (see, Ramey 2011).

11 We also include a deterministic trend and a dummy variable for each country in the sample (country fixed-effects). Real GDP was obtained by deflating nominal GDP by the GDP deflator. For all other variables, the consumer price index (CPI) was used to transform nominal values into real.

12 The following 19 countries are included in the analysis: Algeria, Bahrain, Djibouti, Egypt, Iran, Jordan, Kuwait, Lebanon, Libya, Morocco, Oman, Pakistan, Qatar, Saudi Arabia, Sudan, Syria, Tunisia, United Arab Emirates, and Yemen.
} 
ian likelihood function and a standard diffuse (Jeffrey's) prior on the reduced form parameters $B$ and $\sum$, which implies that the joint posterior density of the parameters is of the NormalWishart form (see, Uhlig 2005, pp. 409-12). We report the median and selected percentiles from this empirical posterior density. Details on how to implement the identification procedure are given in Appendix 2.13

\section{EMPIRICAL FINDINGS}

Table 1 and Figures 1-3 present the estimates of fiscal multipliers for the different country groups. ${ }^{14}$ In using these estimated multipliers, desks should see them mostly as a useful guide for quantifying the impact of fiscal measures or shocks on output in their respective countries. For the average MENAP country, the estimated fiscal multipliers range from 0.4 to 1.2 for government consumption, 0.2 to 0.7 for current spending, 0.6 to 1.4 for government investment spending, and -0.4 for tax revenues.

\begin{tabular}{|c|c|c|c|c|}
\hline & $\begin{array}{l}\text { Current } \\
\text { Spending }\end{array}$ & $\begin{array}{l}\text { Government } \\
\text { Consumption }\end{array}$ & $\begin{array}{c}\text { Government } \\
\text { Investment } \\
\text { Spending }\end{array}$ & $\begin{array}{c}\text { Tax } \\
\text { Revenues }\end{array}$ \\
\hline \multicolumn{5}{|l|}{ By REO classification } \\
\hline GCC & 0.7 & 1.2 & 1.4 & -- \\
\hline MENAP Oil Importers & 0.6 & 1.0 & 1.2 & -- \\
\hline MENAP Oil Exporters & 0.4 & 0.7 & 1.0 & -- \\
\hline ACTs ${ }^{1}$ & 0.5 & 0.7 & 1.2 & -- \\
\hline MENAP & 0.5 & 0.7 & 1.1 & -0.4 \\
\hline \multicolumn{5}{|l|}{ By Economic Fundamentals } \\
\hline More Open to Trade & 0.3 & 0.4 & 1.0 & -- \\
\hline Less Open to Trade & 0.4 & 1.0 & 1.2 & -- \\
\hline High Income & 0.7 & 0.8 & 1.1 & -- \\
\hline Low Income & 0.5 & 0.8 & 1.1 & -- \\
\hline More Flexible Exchange Rate & 0.2 & 0.4 & 0.6 & -- \\
\hline Less Flexible Exchange Rate & 0.7 & 1.1 & 1.3 & -- \\
\hline
\end{tabular}

IMF staff calculations.

${ }^{1}$ Estimates in the table are cumulative maximum multipliers

${ }^{2}$ In the case of the Tax revenues multiplier, MENAP excludes GCC countries, DJI, LBN, LBY, and SDN

3 Excludes Libya

Government investment spending displays the highest multiplier among all spending categories in all MENAP country groups. This is not surprising given that government investment

\footnotetext{
13 Fry and Pagan (2007) note that estimated impulse responses identified by sign-restrictions may contain weak information. However, Paustian (2007) shows that sign restrictions can uncover the true impulse responses, if the variance of the shock under study is sufficiently large. Given that fiscal shocks explain a large portion of the variation in macroeconomic variables in MENAP countries, the use of sign-restrictions for identification is not problematic.

14 Appendix 3 presents the fiscal multiplier estimates along with their confidence bands.
} 
expenditures tend to be growth enhancing, inducing not only short-term effects through their impact on demand, but also long-lasting effects through their potential impact on supply. The estimates for government investment spending are the highest in GCC countries. ${ }^{15}$

\section{Figure 1. Fiscal Multipliers in MENAP}

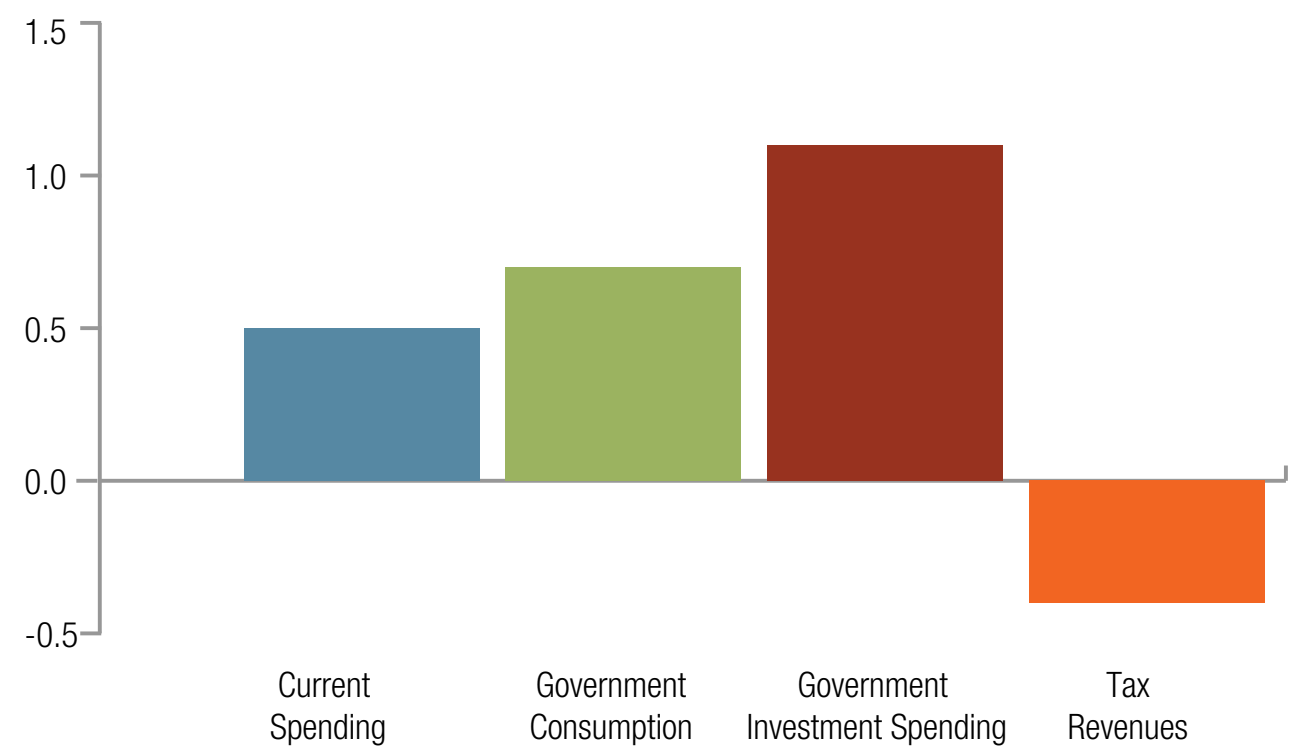

Source: IMF staff estimates.

Estimates of government consumption multipliers are higher than those of current spending multipliers but are generally lower than unity, except in the case of GCC countries where they exceed unity. ${ }^{16}$ Current spending is the sum of government consumption expenditure, and subsidies and transfers. Thus, the lower multiplier estimates for current spending relative to government consumption suggests that the output effects of cuts in subsidies and transfers are modest. Moreover, the relatively high government investment spending multiplier estimates imply that the fiscal savings from cuts to subsidies could be channeled to higher public investment to support and enhance growth, thereby limiting risks to near-term economic activity, especially in the Arab Countries in Transition.

Estimates of fiscal multipliers by country groups based on economic fundamentals also reveal interesting dynamics that are consistent with theory and evidence from the literature. Multipliers for countries with relatively low exchange rate flexibility in MENAP tend to be higher than those for countries with higher exchange rate flexibility. This is consistent with the

\footnotetext{
15 Espinoza and Senhadji (2011) found multipliers in the $0.3-0.7$ range for current spending and 0.6-1.1 for government investment spending, in the case of GCC countries.

16 This may reflect a high multiplier for public wages and salaries in GCC countries.
} 
Mundell-Fleming model which predicts that fiscal policy is more effective in stimulating real output under predetermined exchange rates than under flexible exchange rates. This is mainly because monetary conditions are more accommodative the less flexible the exchange rate.

We also find evidence suggesting those countries that are more open to trade have lower and less persistent fiscal spending multipliers than countries that are less open to trade. This is consistent with the Keynesian view that the size of the multiplier is smaller in a more open economy as a larger portion of the fiscal expansion is diverted to the rest of the world through higher imports (leakages). Finally, while there is no clear evidence that the size of the multiplier differs according to income levels (except in the case of current expenditures), multipliers tend to be relatively more persistent in low-income countries. ${ }^{17}$ These results are consistent with the evidence in IIzetzki, Mendoza, and Végh (2013) who also find that government consumption multipliers are larger in high income economies, economies operating under predetermined exchange rates, and in less open economies.

\section{Figure 2. Fiscal Multipliers in MENAP, by REO Classification}

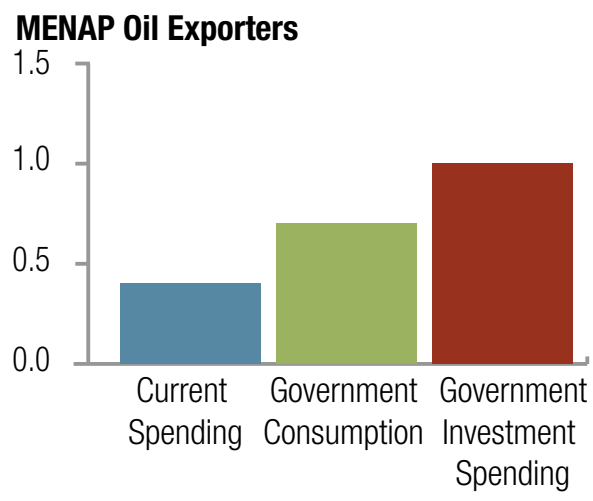

GCC

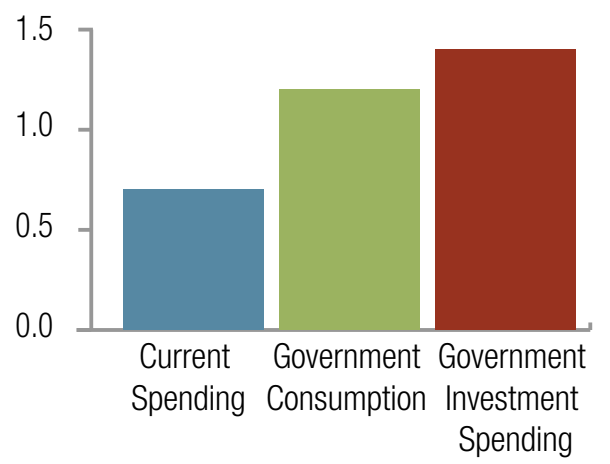

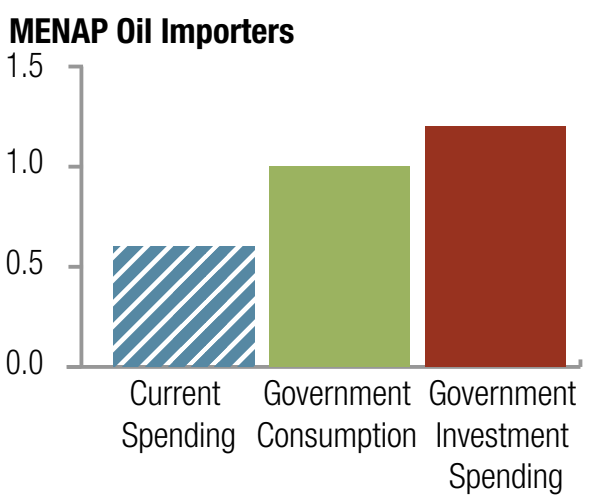

Arab Countries in Transition (ACTs)

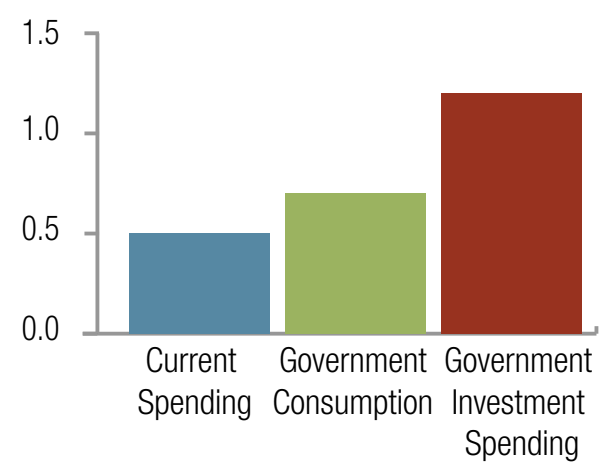

Source: IMF staff estimates.

Note: Stripped bars denote estimates that are not statically significant.

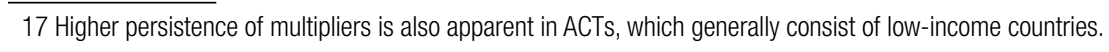


The finding that the tax revenue multiplier is smaller than spending multipliers is consistent with the evidence presented in the literature, including estimates for the United States. This can be explained by basic Keynesian theory, which argues that tax cuts are less effective than spending increases in stimulating the economy, since households may save a portion of the additional after-tax income.

\section{Figure 3. Fiscal Multipliers in MENAP by Economic Fundamentals}
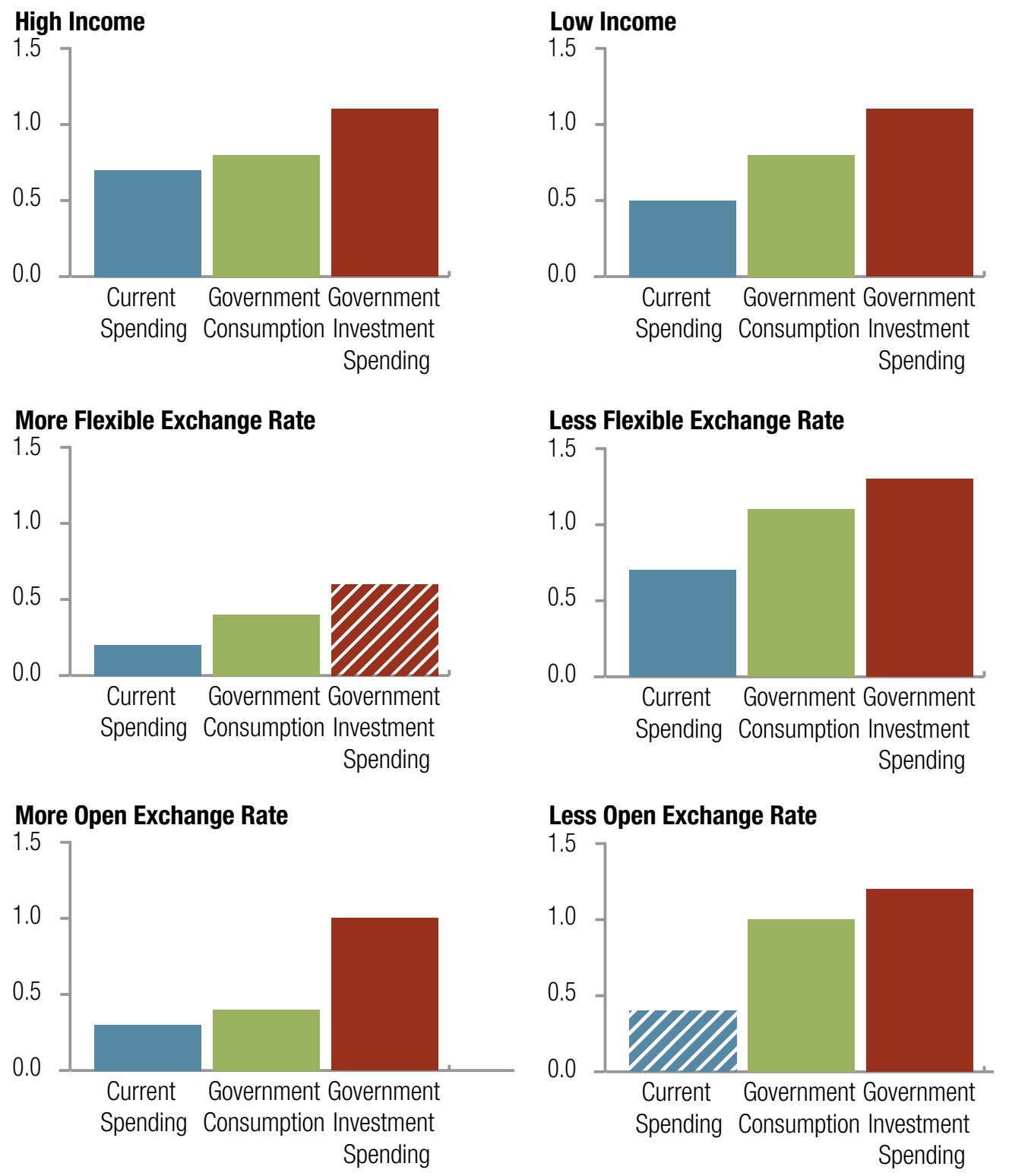

Source: IMF staff estimates.

Note: Stripped bars denote estimates that are not statically significant. 
Staff should be cautious in supporting a specific type of revenue or expenditure consolidation based entirely on the relative size of the multipliers presented in this guidance note. One reason is that the empirical estimates do not control for certain factors which could affect the size of the multiplier such as the state of the economy. Generally speaking, the design of a successful fiscal consolidation package should take into account other factors in addition to the relative size of fiscal multipliers, including the efficiencies of tax and expenditure measures which depend on their initial levels and structure. For instance, while revenue measures may be needed when the envisaged adjustment is relatively large, the current high tax base and tax pressure in some countries suggest that the bulk of their fiscal adjustment may need to be primarily based on the expenditure side.

\section{A "BACK OF THE ENVELOPE" APPROACH}

This section shows how to derive fiscal multipliers based on economic fundamentals, for the case of MENAP countries that were not included in the analysis due to the lack of sufficient data. Desks of these countries could use this back-of-the-envelope approach to impute fiscal multipliers based on selected country-specific characteristics. A similar approach-The "Bucket Approach" - was originally proposed in Batini and others (2013) and was more recently extended in Batini and others (2014). Here, we only broadly follow the approach of Batini and others $(2013,2014)$, which is more comprehensive and extensive than ours. Our approach proceeds as follows:

Step 1: Desks should assess the following characteristics:

- Openness to trade. Use the ratio of imports to non-oil GDP to assess whether a country is more (or less) open to trade, relative to other MENAP countries in the sample.

- Income level. Use data on real GDP per capita to assess whether a country has a relatively high (or low) income, compared to other MENAP countries in the sample.

- Exchange rate flexibility. Assess whether, relative to other MENAP countries in the sample, a country has higher (or lower) exchange rate flexibility.

Step 2: based on the assessment done in step 1, assign a value for the multiplier for each of the three economic fundamentals, using the fiscal multipliers shown in Table 1.

Step 3: take a simple average of the three multiplier values obtained in step 2, to determine the value of the fiscal multiplier, for a given spending category. ${ }^{18}$

For illustration, Table 2 presents the fiscal multiplier values, for a country with relatively low income, greater openness to trade, and lower exchange rate flexibility. The multipliers are $0.8,0.5$, and 1.1 for government consumption, current, and government investment spending, respectively.

$18 \mathrm{It}$ is recommended to use a simple average, given the limited empirical evidence on the relative importance of these three characteristics in determining the size of the fiscal multiplier.

Technical Notes and Manuals 15/01 | 2015

CInternational Monetary Fund. Not for Redistribution 
Table 2. The Bucket Approach

\begin{tabular}{|l|c|c|c|}
\hline & $\begin{array}{c}\text { Current } \\
\text { Spending }\end{array}$ & $\begin{array}{c}\text { Government } \\
\text { Consumption }\end{array}$ & $\begin{array}{c}\text { Government } \\
\text { Investment } \\
\text { Spending }\end{array}$ \\
\hline Low Income & 0.5 & 0.8 & 1.1 \\
Less Open to Trade & 0.3 & 0.4 & 1.0 \\
\hline Less Flexible Exchange Rate & 0.7 & 1.1 & 1.3 \\
\hline Average & 0.5 & 0.8 & 1.1 \\
\hline
\end{tabular}

IMF staff calculations.

\section{The MENAP Fiscal Multiplier Template ${ }^{19}$}

\section{Main Features of the Multiplier Template}

The MENAP fiscal multiplier template is an analytical tool that was built using Microsoft Excel, and is an extension of a recent template prepared by FAD for its Guidance Note on fiscal multipliers. The extension has been made to incorporate the disaggregated nature of the fiscal multipliers that were estimated for MENAP countries. It consists of several worksheets. The "Assumptions" sheet allows the user to select the country of interest, the choice for baseline GDP, the presumed fiscal measures as well as assumptions on the persistence of fiscal shocks. Based on the selected assumptions, data are automatically populated in the "Input Data" sheet. The "Impact" sheet computes the effects of the assumed fiscal shocks-for different expenditure components or for taxes—on real output. It projects real output by impacting a baseline with a set of fiscal shocks using the estimated multipliers, rather than on the primary balance, as in the FAD template. The "Charts" shows graphic displays of the results shown in the "Impact" sheet. Appendix 4 provides a step-by-step guide to using the multiplier template. Below is a brief description of the main features of the MENAP fiscal multiplier template:

- Desks can specify the estimate of baseline GDP to compute the impact of the shocks or measures. To this end, they can use their own estimate of potential output, or alternatively, the potential output series as calculated within the template (using a standard HP filter). Desks can also specify other preferred measure of baseline GDP, as long as such measure does not already include the effects of the assumed fiscal shocks.

- The template is sufficiently flexible, and differentiates between fiscal multipliers for spending and tax revenues. It also differentiates between multipliers for different categories of spending, namely current spending, government consumption, and government investment spending.

- The template allows desks to easily modify the fiscal multiplier assumptions, choosing estimates of the region to which their country belongs, or the group they most closely identify with. Desks can also enter their own multiplier estimates in the template.

- The template allows making projections over a relatively long period of time, taking into account the persistence of the fiscal multiplier effects, and thus the effects of past fiscal

19 The template is available at http://www.imf.org/external/pubs/ft/tnm/2015/data/tnm1501.zip 
shocks. Desks can use the default persistence of multipliers that is embedded in the template, and conduct sensitivity analysis on the effects of shocks on output by varying the level of persistence in the template.

- The template allows desks to specify the different fiscal measures explicitly, rather than proxy them with the change in the structural balance or the cyclically adjusted primary balance. $^{20}$

- Given that efficient government investment spending can strengthen long-term growth prospects, the template allows desks to assume permanent effects on GDP from an increase in such variable.

\section{Using Fiscal Multiplier to forecast Real Output}

The MENAP fiscal multiplier template maintains the simplicity and user-friendliness of the FAD template in incorporating explicit links from the fiscal to the real sector, a task sometimes made difficult by the nature of the financial programming framework at the IMF. Once desks have selected values for the fiscal multipliers and customized inputs, the template computes the effects of fiscal policy on output projections. In particular, the template projects real GDP by impacting a baseline GDP with fiscal shocks. Figure 4 illustrates the impact of fiscal consolidation on output, as generated by the template.

\section{Figure 4. Impact of Fiscal Shocks on Output}

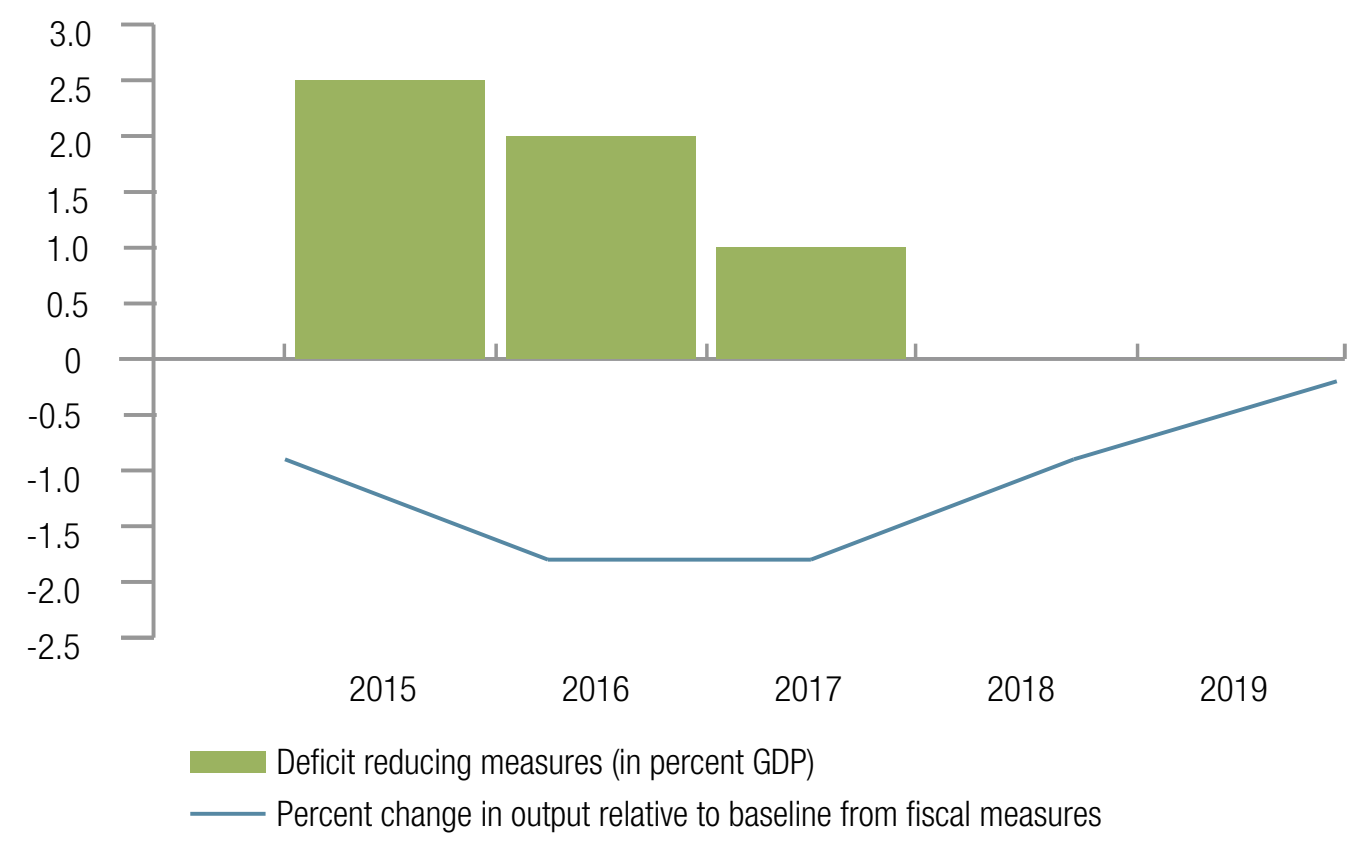

20 This is a departure from the computational approach used in the FAD template. 


\section{Box 1. Minimizing the Effects of Fiscal Consolidation on Growth}

\section{Impact on Output from Fiscal Measures}

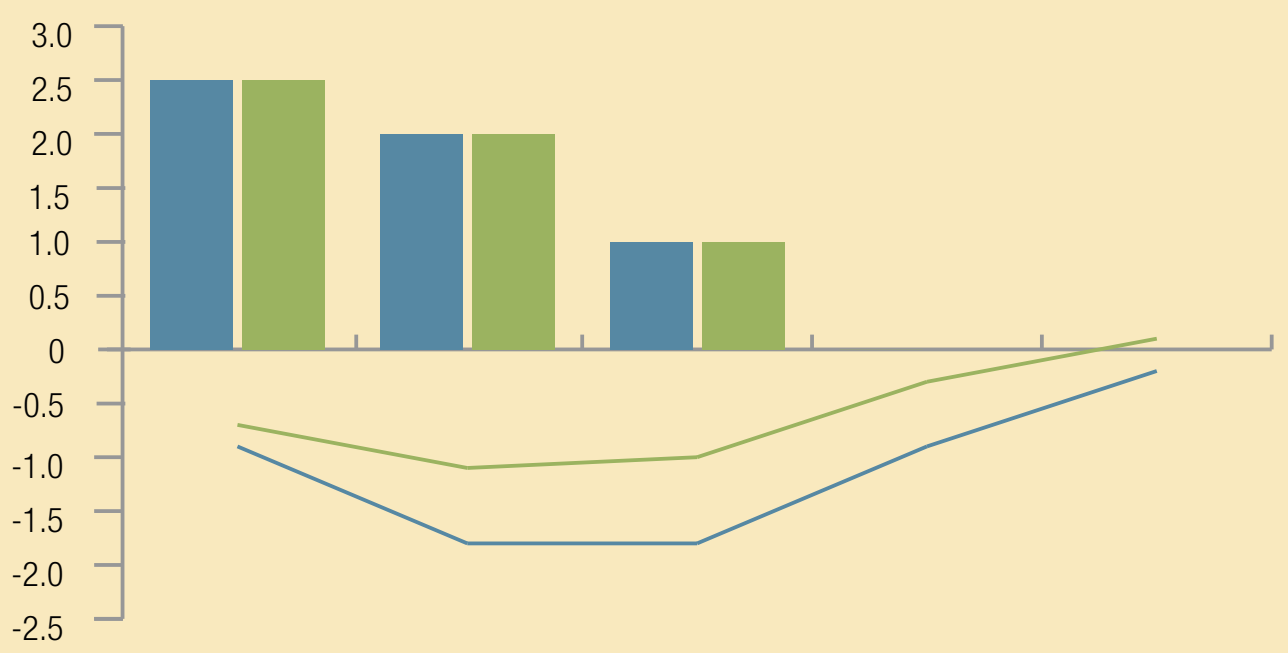

Deficit reducing measures (in percent GDP scenario A)

Deficit reducing measures (in percent GDP scenario $B$ )

_ Percent change in output relative to baseline (scenario $A$ )

_ Percent change in output relative to baseline (scenario B)

With inputs from desks, the template produces a table and a graph showing the impact of fiscal measures on output over the projection period, under a user-specified fiscal adjustment scenario. Desks can then use the template to compare the effects of fiscal adjustment under different scenarios. For illustration, consider two fiscal adjustment scenarios over the medium term, each consisting of a fiscal effort of 5.5 percent of GDP (cumulative), through cuts in subsidies and higher taxes. However, Scenario B also incorporates an increase of 1.5 percentage point of GDP in government investment spending. The effects on output are shown for both scenarios. Given that government investment spending has higher multipliers than current spending and taxes in MENAP countries, the drag on growth from a relatively sizable reduction in current spending and an increase in tax revenues is substantially reduced by a modest increase in government investment expenditures. This allows reducing the fiscal deficit while at the same time support medium-term growth prospects. ${ }^{14}$ 


\section{An Illustration: Comparing the effects of Two Adjustment Scenarios}

In this section, we illustrate one of the policy messages presented in Annex 3 of the MENAP REO (October 2013). Our findings supports the view that current spending multipliers in MENAP countries are lower than government investment spending multipliers, reinforcing the policy message presented in MENAP REO which suggests that successful fiscal consolidation should rely on a policy mix that minimizes the impact on growth, through a reorientation of spending from current to government investment spending. Box 1 illustrates how, under such a policy scenario, risks to short-term economic activity are reduced even when only a small portion of the fiscal savings from consolidation is channeled into higher government investment spending which create jobs, reduce inequities, and strengthen long-term growth prospects. ${ }^{21}$

21 It is important to ensure the effectiveness, quality and efficiency of all growth-enhancing government investment spending by increasing monitoring and implementation capacity. 


\section{APPENDIX 1. DATA DEFINITIONS AND SOURCES}

The data used in the estimation of fiscal multipliers were provided by country desks. All variables were transformed into real terms using the consumer price index, except for real output (which is obtained using the GDP deflator). Fiscal variables in are defined in the same way as in the literature. Below is a list of the variables used and their definition:

- Real output: real gross domestic product (GDP). Non-Hydrocarbon GDP was used for oil exporting countries.

- Real private consumption

- Current spending: total government spending excluding government investment expenditures and interest payments.

- Government consumption: current spending, excluding subsidies and transfers, and interest payments.

- Government investment spending

- Net tax revenues: tax revenues net of transfers.

Country groups according to regional classification are as follows:

- MENAP oil exporters: Algeria, Bahrain, Iran, Kuwait, Libya, Oman, Qatar, Saudi Arabia, the United Arab Emirates, and Yemen.

- MENAP oil importers: Djibouti, Egypt, Jordan, Lebanon, Morocco, Pakistan, Sudan, Syria, and Tunisia.

- The Gulf Cooperation Council (GCC): Bahrain, Kuwait, Oman, Qatar, Saudi Arabia, and the United Arab Emirates.

- The Arab Countries in Transition (ACTs): Egypt, Jordan, Libya, Morocco, Tunisia, and Yemen.

The criteria used to group MENAP countries, based on economic fundamentals are as follows:

- Income level: we defined as "low income" a country whose per capita income (average over the sample) is below the cross-country median, and "high income" otherwise.

- Relative degree of exchange rate flexibility: The coefficient of variation of NEER is used here as a rough measure of exchange rate volatility. We define as having a "less flexible exchange rate" a country whose coefficient of variation of NEER (average over the sample) is below the cross-country median and "more flexible" otherwise.

- Openness to trade: We defined as "more open to trade" a country whose imports as a percent of non-oil GDP exceeds the median across countries in the sample, and "less open to trade" otherwise. 


\section{APPENDIX 2. THE IDENTIFICATION PROCEDURE USING SIGN-RESTRICTIONS}

We explain below the algorithm of identifying the fiscal shocks using the robust sign-restrictions approach, as generalized by Rubio-Ramirez, Waggoner and Zha (2010). The intuition behind the sign restrictions identification procedure is to take a draw from the VAR posterior and then a sub-draw from an orthogonal matrix $Q$, and then proceed to compute the impulse responses in the usual way. If the resulting impulse response satisfies the sign restrictions, the draw is kept and saved. If it doesn't satisfy the sign restrictions, the draw is discarded by giving it a zero prior weight. The process is repeated sufficiently: such iteration generates a distribution for the impulse vectors that we call fiscal shocks. Based on such distribution, we evaluate and report the resulting statistics. The algorithm is Bayesian, and entails the following steps:

- Estimate the reduced form coefficient matrix $\hat{\mathrm{B}}$ and the reduced form variance-covariance matrix $\hat{\Sigma}$ and $\hat{\mathrm{B}}$ by Ordinary least squares.

- Draw $\bar{\Sigma}$ and $\bar{B}$ from the posterior distribution conditional on the OLS estimates from step (1).

- Using the values from this draw, impose the sign restrictions to identify the structural fiscal shocks and business cycle shocks, as follows:

- Draw an $n \times n$ matrix $\mathrm{H}$, element by element, from a standard normal density, and use its 'Q-R' factorization to set $\mathrm{H}=\mathrm{QR}$, where $\mathrm{Q}$ is an orthogonal matrix (QQ' = I) and $\mathrm{R}$ is normalized to have positive diagonal elements.

- Set $\overline{\mathrm{D}}=\overline{\mathrm{S}} \mathrm{Q}$ which implies values for $\mathrm{D}$, and where $\overline{\mathrm{S}}$ denotes the lower-triangular (Cholesky) factor of the covariance matrix of the reduced form errors.

- If the estimates of $\overline{\mathrm{D}}$ do not satisfy the sign restrictions for the government spending, tax revenue and business cycle shocks over the chosen horizon, return to sub-step (3a), draw a new value of $Q$, and continue until the draw of $Q$ yields estimates that satisfy the sign restrictions,

- If the estimates of $\overline{\mathbf{D}}$ satisfy the sign restrictions, compute and save the impulse response of real output to the fiscal shocks. Then, return to step (2) and draw a new set of reduced form parameters.

- Iterate on steps (2) through (3d) until 15,000 draws from the posterior distribution of the dynamic responses of all the variables to the shocks (that satisfy the conditions of step 3d) are produced.

Finally, we report the median and selected percentiles (25th and 75th percentile ranges) from the empirical posterior density. To obtain the estimate of the fiscal multiplier, we multiply the response of real output to fiscal shocks by the average share of the fiscal variable in output, as explained in the note (see, page 5).

Technical Notes and Manuals 15/01 | 2015 


\section{APPENDIX 3. FISCAL MULTIPLIER ESTIMATES AND CONFIDENCE INTERVALS}

\section{Figure 1. MENAP Fiscal Multipliers}
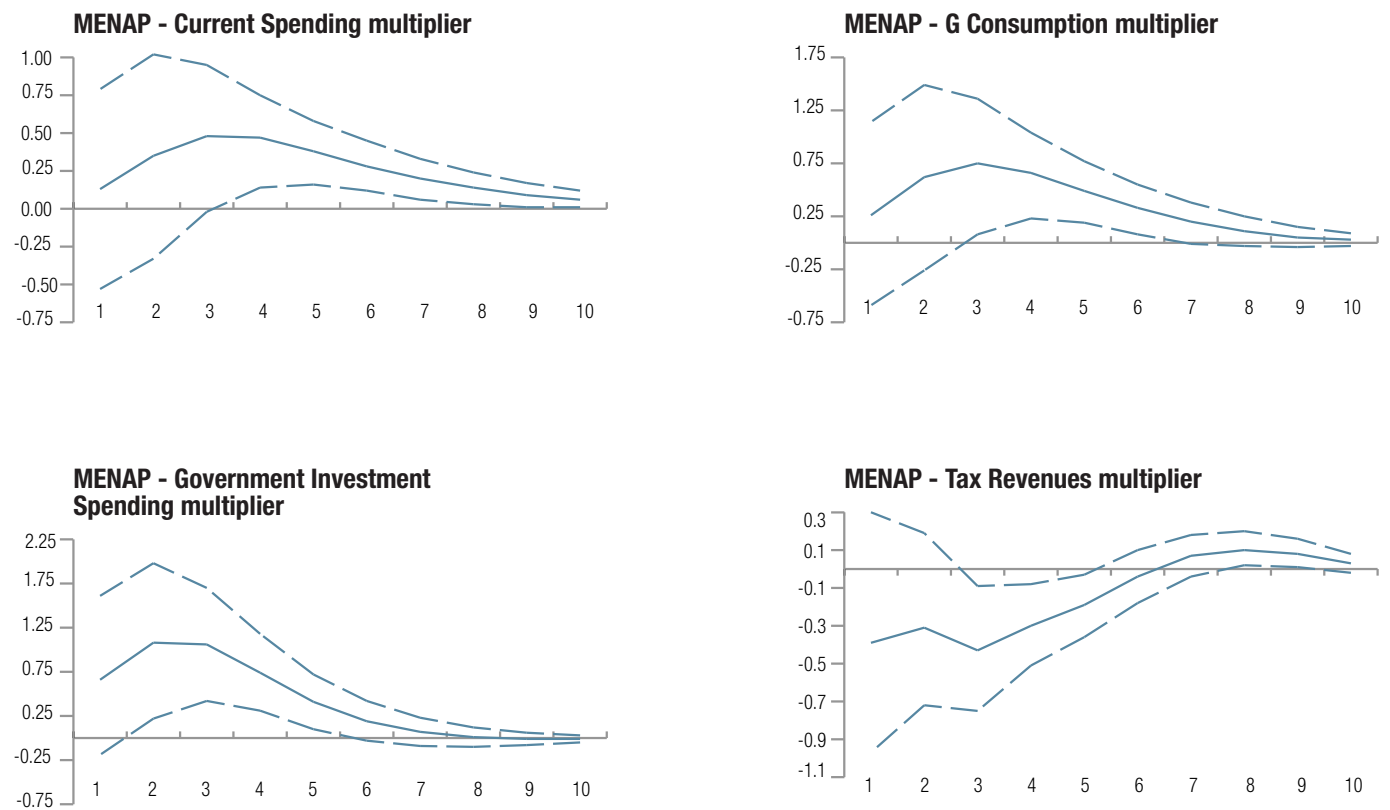

Source: IMF staff estimates.

Note: Dotted lines are 25th and 75th percentile range confidence intervals.

\section{Figure 2. Government Consumption Multipliers, by Regional Classification}
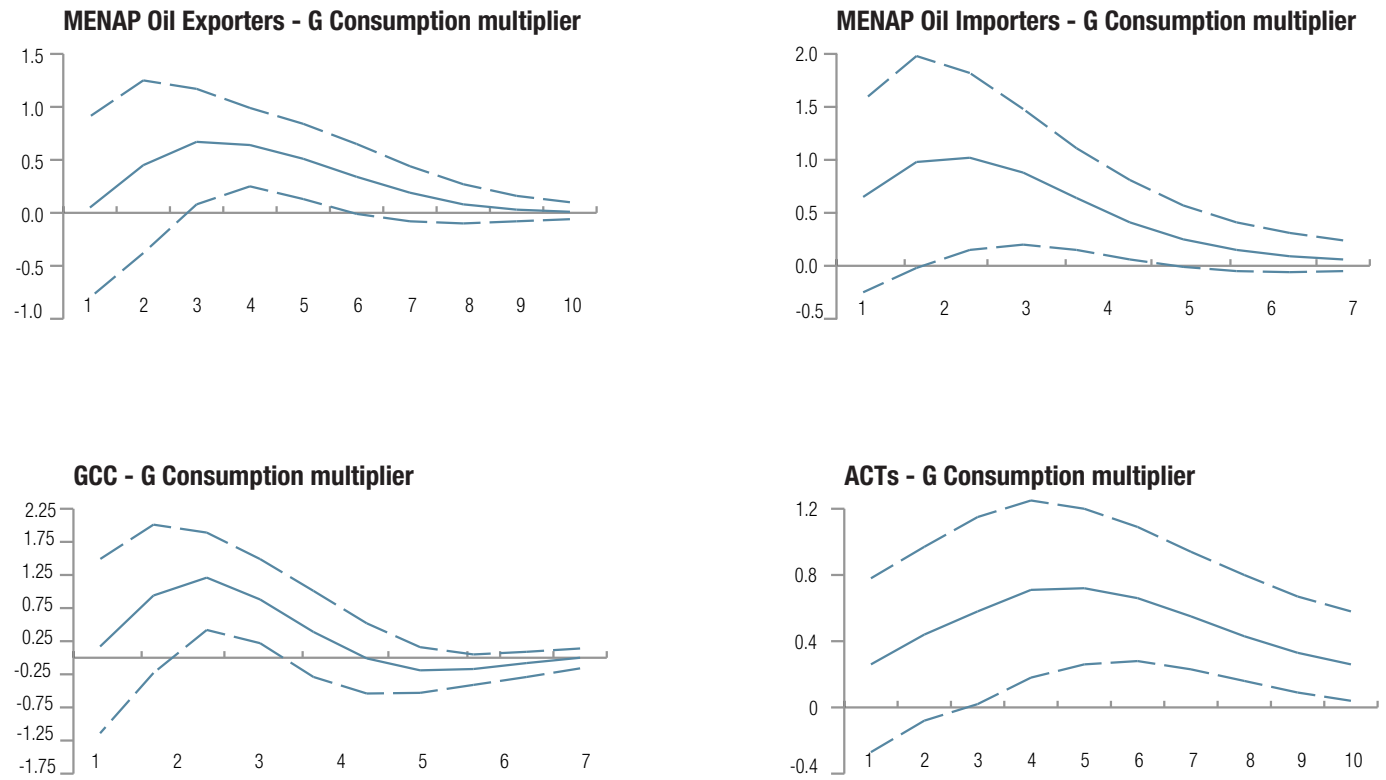

Source: IMF staff estimates.

Note: Dotted lines are 25th and 75th percentile range confidence intervals. 


\section{Figure 3. Current Spending Multipliers, by Regional Classification}
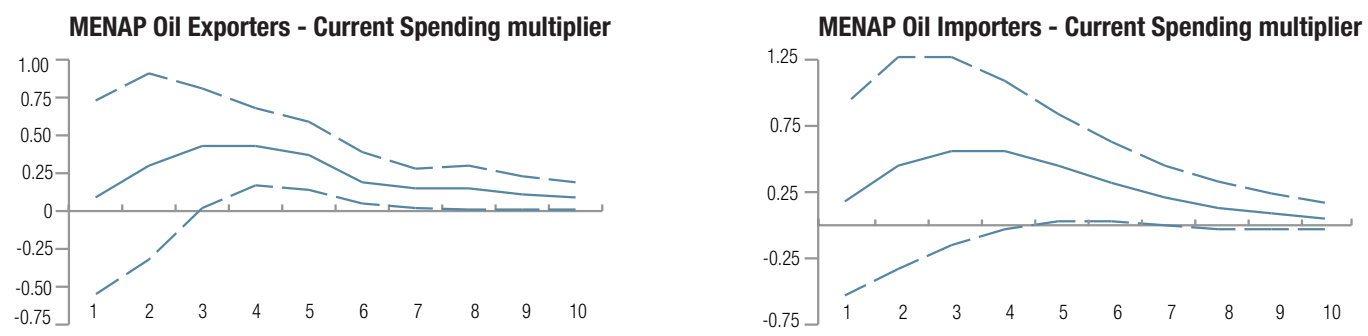

GCC - Current Spending multiplier

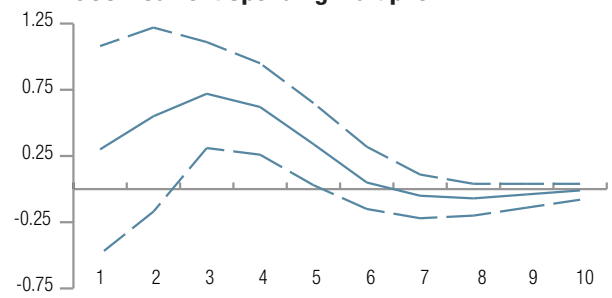

Source: IMF staff estimates.

Note: Dotted lines are 25th and 75th percentile range confidence intervals.

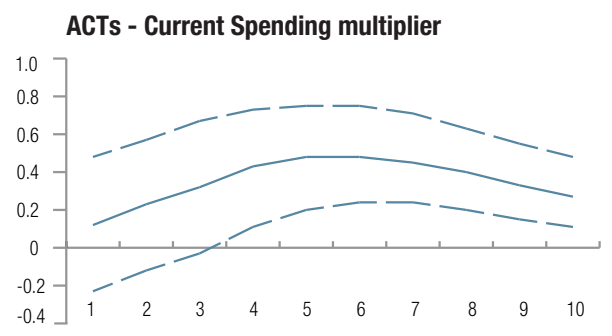

\section{Figure 4. Government Investment Spending Multipliers, by Regional Classification}
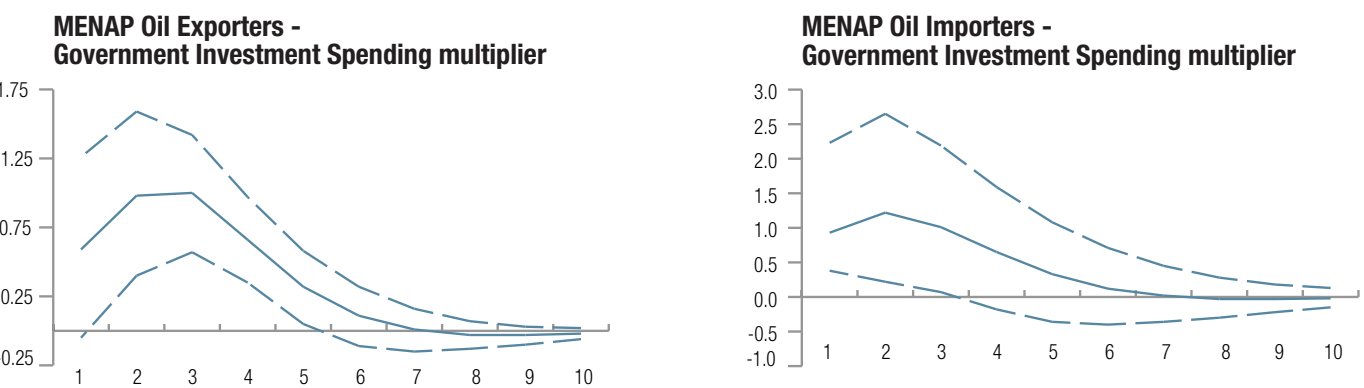

GCC - Government Investment Spending multiplier

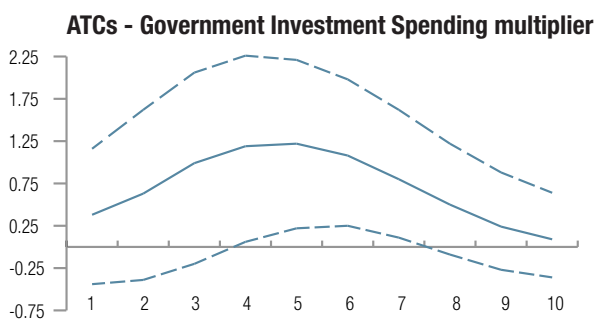

Source: IMF staff estimates.

Note: Dotted lines are 25th and 75th percentile range confidence intervals. 
Figure 5. Current Spending Multipliers, by Economic Fundamentals
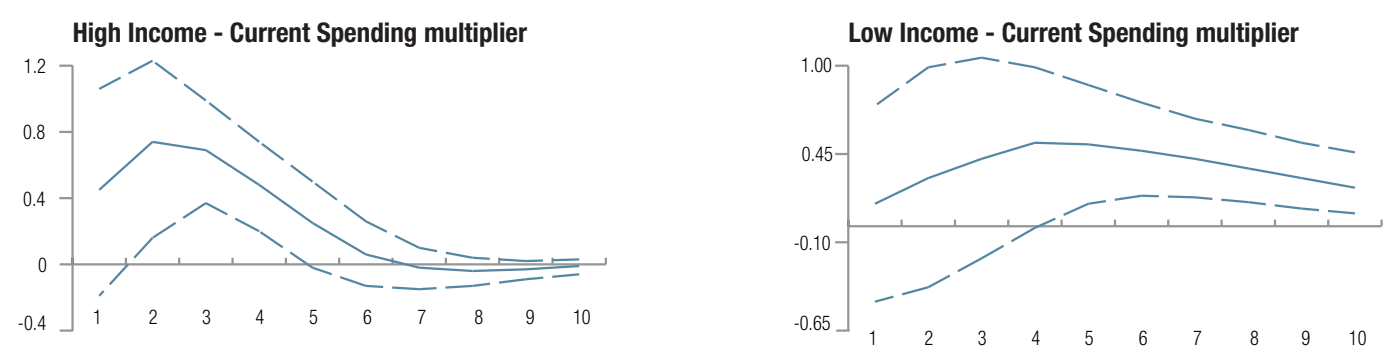

More Flexible Exchange Rate Current Spending multiplier
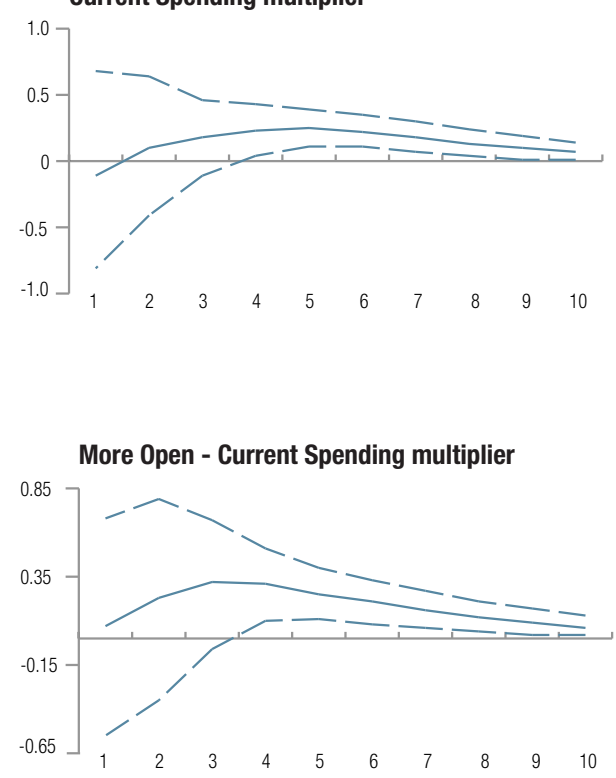
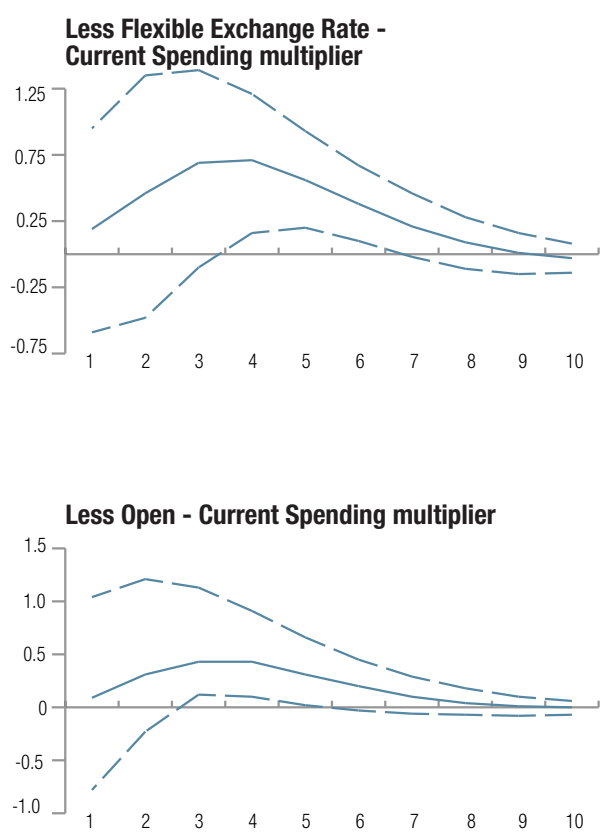

Source: IMF staff estimates.

Note: Dotted lines are 25th and 75th percentile range confidence intervals. 
Figure 6. Government Consumption Multipliers, by Economic Fundamentals
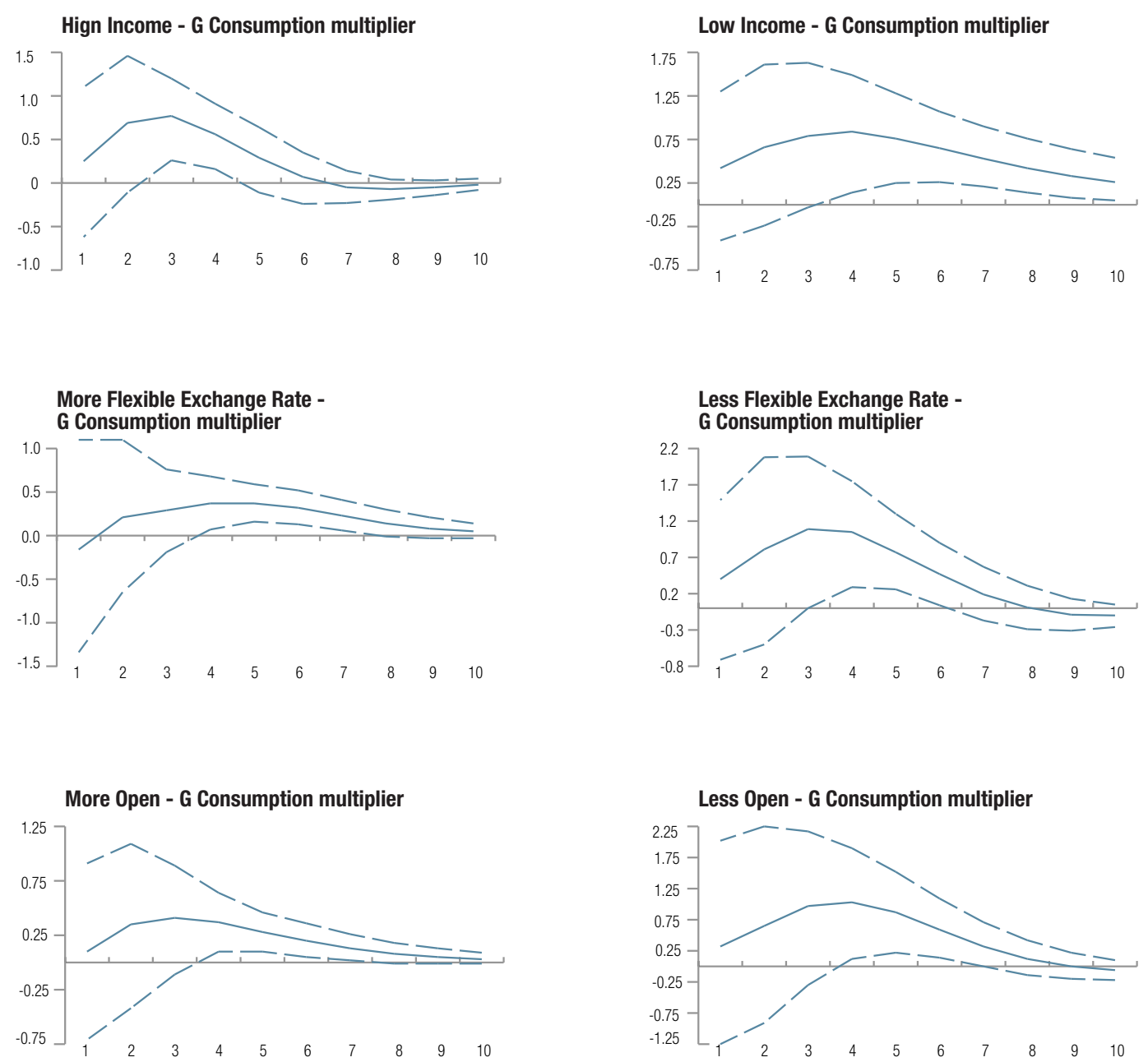

Source: IMF staff estimates.

Note: Dotted lines are 25th and 75th percentile range confidence intervals. 
Figure 7. Government Investment Spending Multipliers, by Economic Fundamentals
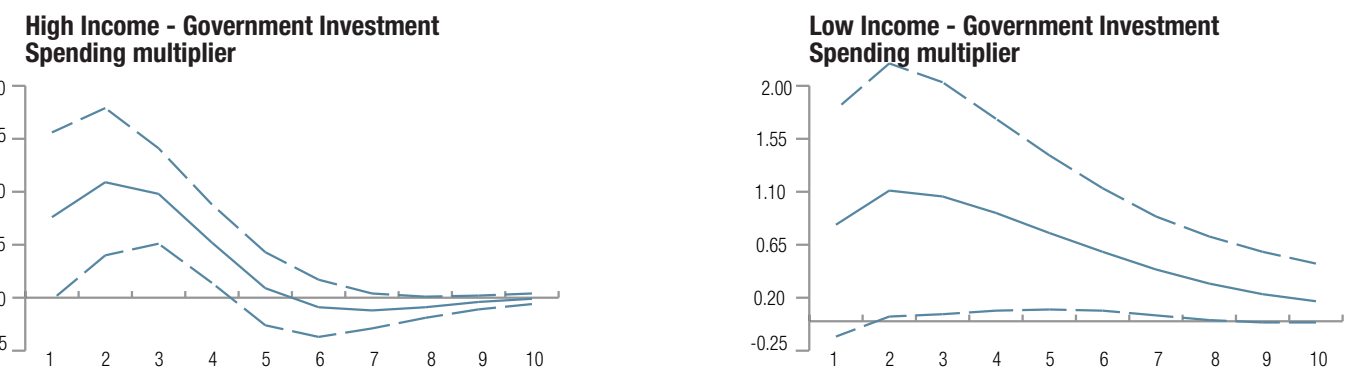

More Flexible Exchange Rate -

Government Investment Spending multiplier

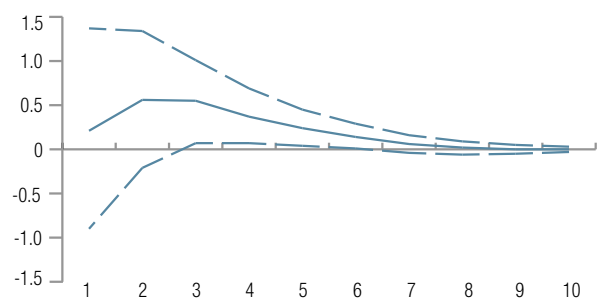

Less Flexible Exchange Rate -

Government Investment Spending multiplier

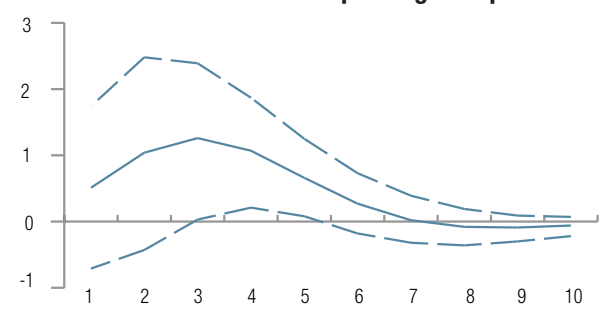

More Open - Government Investment

Spending multiplier
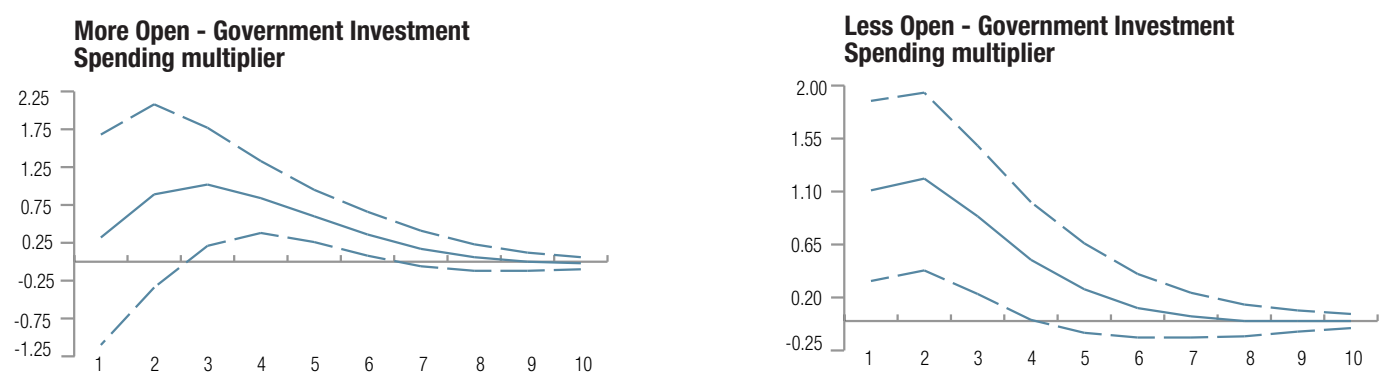

Source: IMF staff estimates.

Note: Dotted lines are 25th and 75th percentile range confidence intervals. 


\section{APPENDIX 4. A STEP-BY-STEP USER GUIDE FOR THE MENAP FISCAL MULTIPLIER}

\section{Overview of the Template}

The MENAP multiplier template is built using Microsoft Excel, based on a recent one prepared by FAD, but is uniquely tailored to the econometric work on fiscal multipliers done in MENAP (see, Table 3). It consists of several worksheets. The "Assumptions" sheet allows the user to select the country of interest, the choice for baseline GDP, the presumed fiscal measures as well as assumptions on the persistence of fiscal shocks. Based on the selected assumptions, data are automatically populated in the "Input Data" sheet. The "Impact" sheet computes the effects of the assumed fiscal shocks on real output, given the assumptions. It projects real output by impacting a baseline with a set of fiscal shocks. The "Charts" shows graphic displays of the results shown in the "Impact" sheet. The template consists of nine worksheets grouped into four categories:

- Reference sheets (black): the "Readme" sheet provide detailed instructions on how to use the template. The "Characteristics" sheet displays the MENAP fiscal multiplier estimates that will be used in the template, as well other country information.

- Input sheets (red): the "Assumptions" sheet is the starting point of the template, where users provide data inputs for the analysis. Users enter information on the choice of fiscal multipliers, the persistence of fiscal shocks, the baseline output series, and the fiscal measures (spending and taxes), among other things. The "Input Data" and "Potential" sheets are populated automatically based on the information specified by the user in the "Assumptions" sheet.

- Computation sheets (yellow)—-the "Multiplier" sheet displays the path of fiscal multipliers based on the choice of fiscal multipliers and the persistence parameters that were assumed by the user. The "Impact" sheet automatically calculates the implied effects of fiscal shocks (measures) on real output.

- Output sheets (green)—these sheets display the results of the fiscal multiplier analysis, as generated by the template.

\section{Using the Template}

Step 1: To initiate the analysis, the user should specify the following basic assumptions in the "Assumptions" sheet:

- The country for which the multiplier analysis will be undertaken (all 31 MENAP countries are included).

- The current year (base year). For example, if the user chooses 2013 as the current year, the first year in the projection period will be 2014 (which will be the starting year for studying the effects of fiscal shocks on output in the template.

- The user also selects the baseline GDP series that will be used to calculate the impact of fiscal shocks. Users can input their own estimate of baseline GDP, or alternatively, use potential output (as calculated using the HP filter within the template, or the WEO/REO 
potential output series as downloaded by the template from EcOS). Irrespective of the choice made, the baseline series should not a priori include the effects of fiscal shocks. Note that the template requires users to install an HP filter Add-in, which can be downloaded from http://www.web-reg.de/hp_addin.html (see, "Potential" sheet in the template for instructions on how to download and install the Add-in).

- The user also makes a choice regarding the level of persistence of the different multipliers. One option is to select the option "User-defined", which gives the user ample flexibility in deciding about the path of the multipliers. Another option is to select "Panel Model Estimated", which loads the default persistence levels that are obtained from the estimation of our models.

\begin{tabular}{|c|c|c|}
\hline \multicolumn{3}{|l|}{ Basic Assumptions: } \\
\hline Assumption & Inputs & Instructions \\
\hline \multicolumn{3}{|l|}{ Country and Date: } \\
\hline Country: & Egypt & \multirow{2}{*}{$\begin{array}{l}\text { Choose country form drop-down menu. Enter the first } \\
\text { year in the projection period. }\end{array}$} \\
\hline Current Year: & 2014 & \\
\hline \multicolumn{3}{|l|}{ Data: } \\
\hline Real Baseline GDP & Potential GDP (HP Filter) & $\begin{array}{l}\text { GDP variable used to compute the impact from mea- } \\
\text { sures. }\end{array}$ \\
\hline \multicolumn{3}{|l|}{ Multiplier Assumptions: } \\
\hline Country Group & MENAP & $\begin{array}{l}\text { Choose the group or region closest to which your } \\
\text { country belongs. }\end{array}$ \\
\hline Persistence & User-Defined & Modify multiplier persistence assumptions \\
\hline $\begin{array}{l}\text { Government Consumption } \\
\text { Subsidies } \\
\text { Government investment } \\
\text { Taxes }\end{array}$ & $\begin{array}{l}\text { Short Persistence ( } 3 \text { Years) } \\
\text { Short Persistence ( } 3 \text { Years) } \\
\text { Long Persistence ( } 5 \text { Years) } \\
\text { Short Persistence ( } 3 \text { Years) }\end{array}$ & Enter user-defined persistence assumptions \\
\hline
\end{tabular}

- Users should also specify the proposed deficit reducing measures (in percent of GDP), noting that they are noncumulative. These measures are the "shocks" that will feed into the fiscal multiplier analysis.

\begin{tabular}{|c|c|c|c|c|c|c|}
\hline \multicolumn{7}{|l|}{$\begin{array}{l}\text { Non-Cumulative Fiscal Measures in percent of GDP } \\
\text { (in percent of Non-Hydrocarbon GDP for Oil Exporters) }\end{array}$} \\
\hline & 2014 & 2015 & 2016 & 2017 & 2018 & 2019 \\
\hline $\begin{array}{l}\text { Government Consumption (Wages, Purchase of Goods } \\
\text { and Services, etc.) }\end{array}$ & 0.0 & 0.0 & 0.0 & 0.0 & 0.0 & 0.0 \\
\hline Subsidies & 0.0 & -1.5 & -1.0 & -0.5 & 0.0 & 0.0 \\
\hline Government investment Expenditure & 0.0 & 0.0 & 0.0 & 0.0 & 0.0 & 0.0 \\
\hline Tax Revenue & 0.0 & 1.0 & 1.0 & 0.5 & 0.0 & 0.0 \\
\hline Deficit Reducing Measures & 0.0 & 2.5 & 2.0 & 1.0 & 0.0 & 0.0 \\
\hline
\end{tabular}


Step 2: Next, under the EcXL tab, connect to EcOS. Then, go to the "Input Data" sheet and click on "refresh" to upload the most recent WEO/REO data on national accounts that are needed to calculate the effects of fiscal shocks (measures) on real output in subsequent sheets.

Step 3: If the HP filter option was selected in step 1, the user should refer to the instructions for installing and using the HP filter Excel add-in (see, bottom of the "Potential" sheet).

Step 4: The fiscal multiplier analysis results are displayed in the following two sheets:

- The "Adjustment" sheet provides a table containing the effects of the fiscal shocks on real output (in levels, and in percent of GDP).

- The "Charts" sheet provides a graphical account of the fiscal multiplier analysis, as displayed in the table above.

\begin{tabular}{|l|c|c|c|c|c|c|c|c|c|c|}
\hline Analysis of Fiscal Measures on Output \\
\hline & $\mathbf{2 0 1 3}$ & $\mathbf{2 0 1 4}$ & $\mathbf{2 0 1 5}$ & $\mathbf{2 0 1 6}$ & $\mathbf{2 0 1 7}$ & $\mathbf{2 0 1 8}$ & $\mathbf{2 0 1 9}$ \\
\hline & \multicolumn{6}{|c|}{ (In Levels, Unless Otherwise Indicated) } \\
\hline Real GDP & 609 & 623 & 649 & 675 & 702 & 730 & 760 \\
\hline Baseline Real GDP & 617 & 638 & 659 & 681 & 704 & 726 & 749 \\
\hline $\begin{array}{l}\text { Total change in output relative to baseline from } \\
\text { fiscal impact }\end{array}$ & & 0.0 & -6.0 & -12.5 & -12.5 & -6.3 & -1.6 \\
\hline In Percent of GDP & & 0.0 & -0.9 & -1.8 & -1.8 & -0.9 & -0.2 \\
\hline $\begin{array}{l}\text { Baseline GDP with the impact of discretionary } \\
\text { fiscal policy }\end{array}$ & 617 & 638 & 653 & 669 & 691 & 720 & 748 \\
\hline & & $($ In Levels, Unless 0 0therwise Indicated) & \\
\hline Real GDP & 2.1 & 2.3 & 4.1 & 4.1 & 4.0 & 4.0 & 4.0 \\
\hline Baseline Real GDP & & 3.4 & 3.4 & 3.3 & 3.3 & 3.2 & 3.1 \\
\hline $\begin{array}{l}\text { Baseline Real GDP with the impact of } \\
\text { discretionary fiscal policy }\end{array}$ & & 3.4 & 2.4 & 2.4 & 3.3 & 4.2 & 3.8 \\
\hline Deficit reducing measures & & 0.0 & 2.5 & 2.0 & 1.0 & 0.0 & 0.0 \\
\hline
\end{tabular}




\section{Impact on Output from Fiscal Measures}

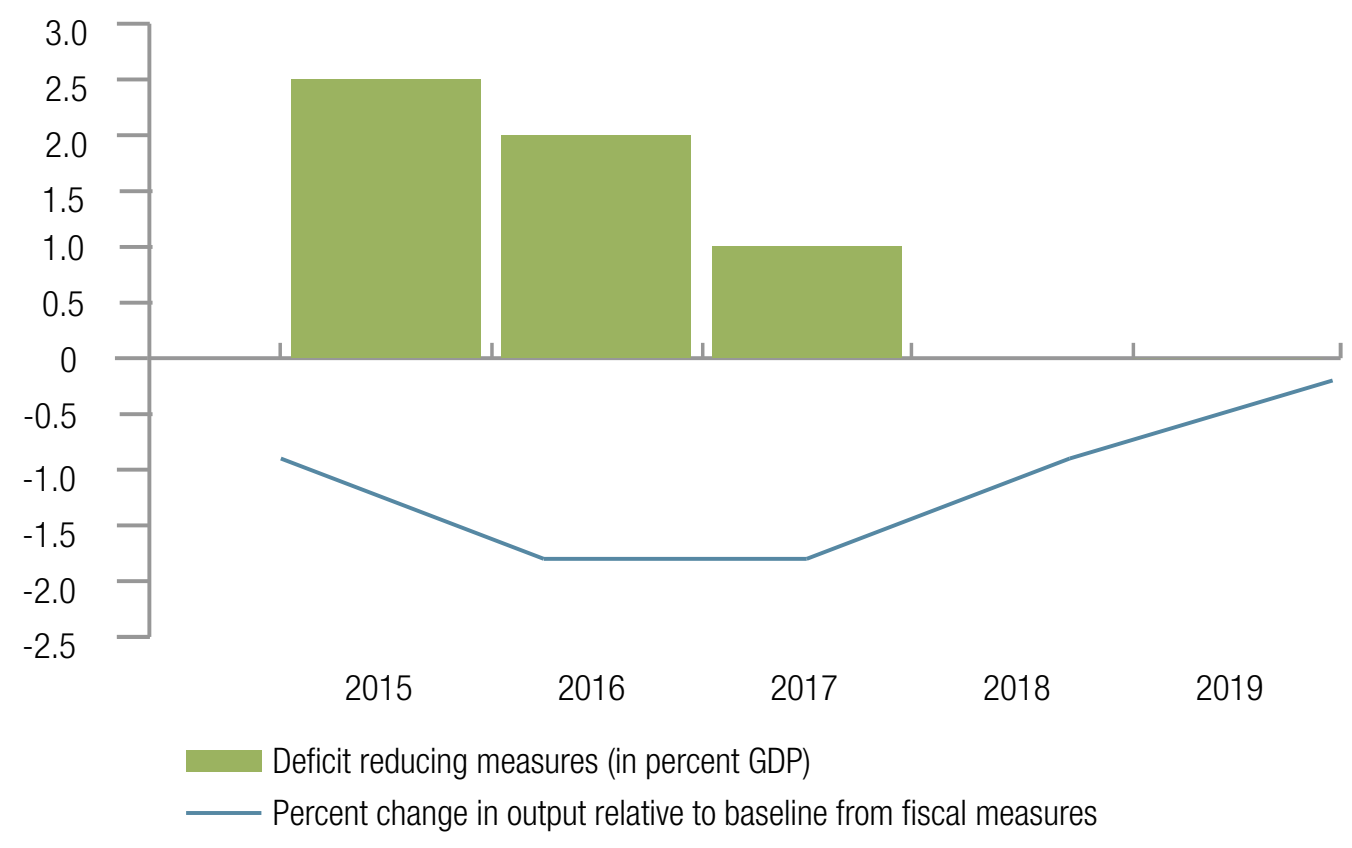




\section{REFERENCES}

Abdallah, C., Cerisola M., Davies V., and M. Fischer, 2015 , "The Effects of Fiscal Policy Shocks on Output: Evidence from MENAP Countries," forthcoming IMF Working Paper.

Abdallah, C., and W. D. Lastrapes, 2013, "Evidence on the Relationship Between Housing and Consumption in the US: A State-Level Analysis," Journal of Money Credit and Banking, No. 45 Vol. 4, pp. 559-90.

Baum, A., M. Poplawski-Ribeiro and A. Weber, 2012, "Fiscal Multipliers and the State of the Economy," IMF Working Paper 12/286 (Washington: International Monetary Fund).

Batini, N., Jovanovic, N., Stepanyan, V., Gust, C., Eyraud, L., and A. Weber, 2013, "Brief Guidance Note for EUR Desks on Fiscal Multipliers," unpublished manuscript, European Department.

—_, Eyraud L., and Weber, 2014. "A Simple Method to Compute Fiscal Multipliers," Forthcoming IMF Working Paper

Blanchard O. and Daniel Leigh, 2013, "Growth Forecast Errors and Fiscal Multipliers," IMF Working Paper 13/1 (Washington: International Monetary Fund).

and R. Perotti, 2002, "An Empirical Characterization of the Dynamic Effects of Changes in Government Spending and Taxes on Output". Quarterly Journal of Economics, No. 117 Vol. 4, pp. 1329-68.

Christiano, L., Martin Eichenbaum, and Sergio Rebelo, 2010, "When is the Government Spending Multiplier Large?" Northwestern University, unpublished.

Espinoza R, and Senhadji A., 2011, "How Strong are Fiscal Multipliers in the GCC? An Empirical Investigation," IMF Working Paper 11/61 (Washington: International Monetary Fund).

Eyraud L., Forni L., Weber A., and N. Batini, 2013, "Guidance Note for Desks on Fiscal Multipliers," (Washington: International Monetary Fund, Fiscal Affairs Department).

_ _ - 2014, "Guidance Note for Desks on Fiscal Multipliers," IMF Technical Notes and Manuals, forthcoming, (Washington: International Monetary Fund).

Ilzetzki, E, Mendoza, E. G, Végh, C., 2013, “How Big (Small?) Are Fiscal Multipliers?” Journal of Monetary Economics, Issue 2, Vol. 60, pp. 239-54.

Kochhar, K, Loungani, P, Salgado, R, and B. Clements, 2013, "Guidance Note on Jobs and Growth Issues in Surveillance and Program Work," IMF Policy Paper, September 27, 2013, (Washington: International Monetary Fund). 
Mountford A, and Uhlig H., 2009, "What are the effects of fiscal policy shocks?" Journal of Applied Economics, No. 24, pp. 960-92.

Paustian, M., 2007, "Assessing sign restrictions," The B.E. Journal of Macroeconomics (Topics), 7.

Ramey V., 2011, "Identifying Government Spending Shocks: It's All in the Timing," Quarterly Journal of Economics, No. 126, pp. 1-50.

Rubio-Ramirez J., Waggoner D, and T. Zha, 2010, "Structural Vector Autoregressions: Theory of Identification for Inference," Review of Economic Studies, Issue 2, Vol. 77, pp. 665-96.

Spilimbergo, A., S. Symansky and M. Schindler, 2009, "Fiscal Multipliers," IMF Staff Position Note 09/11 (Washington: International Monetary Fund).

Uhlig H., 2005, "What Are the Effects of Monetary Policy? Results from an Agnostic Identification Procedure," Journal of Monetary Economics, Vol. 52, pp. 381-419. 